\title{
PENGGUNAAN HORMON PERTUMBUHAN REKOMBINAN TERHADAP PERTUMBUHAN IKAN SELAIS (Ompok hypopthalmus)
}

\section{THE USE OF RECOMBINANT GROWTH HORMONE ON THE GROWTH OF SELAIS FISH (Ompok hypopthalmus)}

\section{Maulina Sawitri $^{1}$, Usman M. Tang ${ }^{1}$, Henni Syawal ${ }^{1}$}

${ }^{1}$ Kekhususan Budidaya

Perairan Magister Ilmu Kelautan, Fakultas Perikanan dan Kelautan, Soebrantas Km 12,5 Simpang Baru, Panam-Pekanbaru Indonsia 28293

Correspondence Author:maulina_sawitri@yahoo.com

A R T I CLE IN FO

Submitted: 25 Mei 2018

Revised :01 Juni 2018

Approved: 05 Juli 2018

\section{Kata kunci:}

Hormon pertumbuhan rekombinan, Pertumbuhan,

Ompok hypopthalmus

\begin{abstract}
This study was aimed to determine the best dose of recombinant growth hormone on the growth of selais fish (Ompok hypopthalmus). This study used a complete randomized desigh with one factor that is recombinant growth hormone dose and 3 repetition. The dose given were $0 \mathrm{mg} / \mathrm{kg}$, $6 \mathrm{mg} / \mathrm{kg}, 12 \mathrm{mg} / \mathrm{kg}, 18 \mathrm{mg} / \mathrm{kg}$ and $24 \mathrm{mg} / \mathrm{kg}$. The results showed that addition of $\mathrm{rElGH}$ at dose of $12 \mathrm{mg} / \mathrm{kg}$ were the best dose for selais fish growth's parameters; absolute length growth $(3,60 \pm 0,6 \mathrm{~cm})$, absolute weight growth $(3,85 \pm 0,46$ $g)$, daily growth rate $(5,56 \pm 0,32 \%)$, food convertion ratio $(1,10 \pm 0,12)$, protein and fat retention $(46,73 \pm 21,34 \%$ and $103,83 \pm 21,43 \%)$. The highest level of glycogen muscle $(22,43 \pm 0,61 \mathrm{mg} / \mathrm{g})$ was found in addition of $\mathrm{rElGH}$ at dose of $18 \mathrm{mg} / \mathrm{kg}$.
\end{abstract}

\begin{abstract}
Abstrak
Penelitian ini bertujuan untuk menentukan dosis yang terbaik dari pemberian hormone pertumbuhan rekombinan terhadap pertumbuhan ikan selais (Ompok hypopthalmus). Penelitian ini menggunakan Rancangan Acak Lengkap dengan 1 faktor, yaitu dosis hormon pertumbuhan rekombinan dan 4 kali ulangan. Adapun perlakuan berupa dosis hormon yang diberikan adalah $0 \mathrm{mg} / \mathrm{kg}, 6 \mathrm{mg} / \mathrm{kg}, 12 \mathrm{mg} / \mathrm{kg}, 18 \mathrm{mg} / \mathrm{kg}$ dan $24 \mathrm{mg} / \mathrm{kg}$. Ikan dipelihara dalam wadah keramba berukuran 1 x 1 x $1 \mathrm{~m}^{3}$ sejumlah 20 unit. Hasil penelitian menunjukkan bahwa pemberian $\mathrm{r} E l \mathrm{GH}$ pada dosis $12 \mathrm{mg} / \mathrm{kg}$ pakan memberikan hasil terbaik terhadap parameter pertumbuhan ikan selais, yaitu pertumbuhan panjang mutlak 3,60 $\pm 0,6 \mathrm{~cm}$, petumbuhan bobot mutlak 3,85 $\pm 0,46 \mathrm{~g}$, laju pertumbuhan harian 5,56 $\pm 0,32 \%$, rasio konversi pakan 1,10 $\pm 0,12$. Nilai retensi protein dan lemak tertinggi juga terdapat pada ikan yang diberi pakan dengan penambahan $\mathrm{r} E l \mathrm{GH}$ dengan dosis $12 \mathrm{mg} / \mathrm{kg}$ yaitu $46,73 \pm 21,34 \%$ dan $103,83 \pm 21,43 \%$. Sedangkan kadar glikogen otot tertinggi $(22,43 \pm 0,61 \mathrm{mg} / \mathrm{g})$ terdapat pada pemberian $\mathrm{r} E l \mathrm{GH}$ dengan dosis $18 \mathrm{mg} / \mathrm{kg}$ pakan.
\end{abstract}




\section{PENDAHULUAN}

$\begin{array}{clr}\text { Ikan } & \text { selais } & \text { (Ompok } \\ \text { hypophthalmus) } & \text { merupakan } & \text { maskot }\end{array}$ Kota Pekanbaru. Ikan selais adalah ikan air tawar yang mempunyai nilai gizi yang cukup tinggi (kadar air 75,01\%, protein $17,06 \%$, lemak $0,44 \%$ dan abu $1,43 \%$ (Desmelati et al., 2013)) serta rasa dagingnya cukup lezat dan gurih. Dalam perdagangannya ikan selais digolongkan sebagai ikan air tawar kelas 1 (satu), karena banyaknya permintaan ikan selais di pasar akan mengakibatkan banyaknya tangkapan ikan selais di alam sehingga populasinya di alam mulai menurun. Upaya domestikasi dan pemijahan buatan telah berhasil dilakukan pada ikan selais (Putra et al., 2011). Upaya budi daya berupa pembesaran ikan selais juga telah dilakukan diantaranya dengan penambahan hormon tiroksin dalam pakan (Putra et al., 2011; Rosyadi, 2015), pemberian mineral besi (Fe) untuk pertumbuhan dan pematangan gonad (Tang dan Alawi, 2015) dan budi daya dengan resirkulasi sistem akuaponik (Putra dan Pamukas, 2011), namun belum memberikan hasil yang cukup memuaskan karena masih rendahnya tingkat laju pertumbuhan harian ikan selais.

Latar (2010) menyatakan bahwa sejak tahun 1980-an peneliti telah berhasil mengisolasi gen hormon pertumbuhan dan memproduksi hormon pertumbuhan rekombinan (rGH) dari beberapa jenis ikan. Beberapa rGH ikan di Indonesia juga telah diproduksi dan diuji bioaktivitasnya dalam memacu laju pertumbuhan ikan seperti rGH ikan mas $(\mathrm{rCc} \mathrm{GH})$, ikan gurame $(\mathrm{r} O g \mathrm{GH})$ dan ikan kerapu kertang (rEIGH) (Alimuddin et al., 2010).

Penggunaan rGH untuk menstimulasi pertumbuhan ikan telah banyak dilakukan dan terbukti dapat meningkatkan laju pertumbuhan ikan diantaranya pada ikan nila
((Oreochromis niloticus) (Latar, 2010), ikan sidat (Anguilla sp.) (Handoyo, 2012), ikan gurame (Osphronemus gouramy) (Tasik, 2013), ikan patin siam (Pangasianodon hypopthalmus) (Sudrajat, 2013), ikan betok (Anabas testudineus, Bloch) (Abbas, 2013), udang galah (Macrobrachium rosenbergii) (Prihardianto, 2014), ikan lele sangkuriang (Triwinarso et al., 2014), ikan $m$ aanvish (Pterophyllum scalare) (Wijaya, 2015), udang vaname (Litopenaeus vannamei) (Saputra, 2016), dan ikan botia (Chromobotia macracanthus) (Permana, 2016).

\section{METODE PENELITIAN Waktu dan Tempat}

Penelitian ini dilaksanakan selama 30 hari pada bulan November 2017 di Laboratorium Pembenihan dan Pemuliaan Ikan Jurusan Budi Daya Perairan Fakultas Perikanan dan Kelautan Universitas Riau.

Penelitian ini menggunakan metode eksperimen menggunakan Rancangan Acak Lengkap dengan satu faktor yang terdiri atas lima perlakuan dan untuk mengurangi kekeliruan dilakukan empat kali ulangan. Adapun perlakuan tersebut adalah penambahan hormon pertumbuhan rekombinan ikan kerapu kertang $(\mathrm{r} E I \mathrm{GH})$ dengan dosis 0 $\mathrm{mg} / \mathrm{kg}, 6 \mathrm{mg} / \mathrm{kg}, 12 \mathrm{mg} / \mathrm{kg}, 18 \mathrm{mg} / \mathrm{kg}$ dan $24 \mathrm{mg} / \mathrm{kg}$.

\section{BAHAN DAN ALAT}

Bahan-bahan yang digunakan dalam penelitian ini yaitu benih ikan selais dengan berat $0,89 \mathrm{~g}$ dan panjang $6,88 \mathrm{~cm}$, pakan buatan pellet komersil terapung FF-999, hormon pertumbuhan rekombinan ikan kerapu kertang (rEIGH), PBS (phosphate buffer saline) dan kuning telur ayam.

Wadah yang digunakan untuk pembesaran ikan selais ini adalah

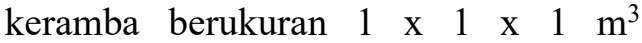
sejumlah 20 unit yang ditempatkan dalam bak beton dan dilengkapi dengan peralatan aerasi, nampan, timbangan 
analitik, DO meter, $\mathrm{pH}$ meter, thermometer, mistar dan kertas millimeter, spektrofotometer, dan tangguk.

\section{Parameter yang diukur}

Parameter yang diukur dalam penelitian ini antara lain partum-buhan bobot mutlak, pertumbuhan panjang mutlak, laju pertumbuhan harian, tingkat kelulushidupa, rasio konversi pakan, retensi protein dan lemak, dan kadar glikogen otot.

Data kuantitatif dari masingmasing perlakuan dianalisis dengan one way Anova. Data disajikan sebagai rataan \pm standar error $(\mathrm{SE})$, menggunakan program SPSS seri 16. Jika terdapat perbedaan yang signifikan (95\%) antar perlakuan maka dilakukan uji lanjut Newman-Keuls.

\section{HASIL DAN PEMBAHASAN}

\section{Pertumbuhan}

Parameter pertumbuhan ikan selais selama penelitian dapat dilihat pada Tabel 1 berikut ini.



Laju pertumbuhan tertinggi diperoleh pada perlakuan dengan pemberian $\mathrm{r} E l \mathrm{GH}$ pada dosis $12 \mathrm{mg} / \mathrm{kg}$, 
yaitu sebesar 5,56\% diikuti oleh dosis 6 $\mathrm{mg} / \mathrm{kg}$, yaitu sebesar $5,14 \%$. Sedangkan laju pertumbuhan harian terendah selama penelitian terdapat pada perlakuan kontrol (tanpa pemberian $\mathrm{r} E l \mathrm{GH})$.

Laju pertumbuhan harian ikan menunjukkan besaran persentase pertumbuhan ikan setiap harinya. Pada Tabel 4 di atas terlihat bahwa pemberian $\mathrm{r} E l \mathrm{GH}$ dapat meningkatkan laju pertumbuhan harian ikan selais dibandingkan kontrol. Pemberian $\mathrm{r} E l \mathrm{GH}$ pada dosis $12 \mathrm{mg} / \mathrm{kg}$ memberikan hasil terbaik pada pertumbuhan panjang mutlak, pertumbuhan bobot mutlak, dan laju pertumbuhan harian ikan selais. Namun pada perhitungan pertumbuhan panjang dan bobot mutlak serta laju pertumbuhan harian juga terlihat adanya penurunan pertumbuhan dan laju pertumbuhan pada dosis rElGH yang lebih tinggi, yaitu $18 \mathrm{mg} / \mathrm{kg}$ dan 24 $\mathrm{mg} / \mathrm{kg}$ dimana benih ikan selais tidak mengalami peningkatan pertumbuhan.

Hal ini menunjukkan adanya negative feedback pemberian $\mathrm{rElGH}$ jika dilakukan berlebihan. Dengan kata lain, dosis rElGH $12 \mathrm{mg} / \mathrm{kg}$ merupakan dosis optimum untuk meningkatkan pertumbuhan ikan selais. Hal yang sama juga ditemukan oleh Handoyo (2012) dimana ikan sidat yang direndam pada dosis rElGH yang lebih tinggi dari 12 $\mathrm{mg} / \mathrm{kg}$ juga tidak mengalami kenaikan pertumbuhan jika dibandingkan dengan kontrol. Handoyo (2012) mengemukakan bahwa negative feedback terjadi secara hormonal, yaitu IGF-1 akan menekan pituitari dalam memproduksi GH apabila konsentrasi $\mathrm{GH}$ dalam tubuh berlebihan, yang menunjukkan bahwa pemberian rGH harus dilakukan dalam dosis yang tepat untuk mendapatkan efek yang optimum. Hal yang sama juga dijelaskan oleh Wong et al. dalam Apriliana et al. (2017) bahwa pada pemberian dosis rGH yang lebih tinggi, organ target yang telah mengalami pertumbuhan akan memberikan rangsangan negatif kepada kelenjar pituitari untuk menghambat kerja dari GH yang masuk ke dalam hati sehingga terjadi perlambatan pertumbuhan.

Pertumbuhan panjang mutlak tertinggi ikan selais selama masa pemeliharaan terdapat pada perlakuan pemberian $\mathrm{r} E / \mathrm{GH} \quad 12 \mathrm{mg} / \mathrm{kg}$, yaitu sebesar 3,60 cm. Sedangkan pertumbuhan panjang terendah ikan selais terdapat pada perlakuan kontrol (tanpa penambahan $\mathrm{r} E l \mathrm{GH}$ ), yaitu sebesar $2,08 \mathrm{~cm}$.

Pertumbuhan bobot mutlak tertinggi ikan selais selama penelitian terdapat pada pemberian hormon kerapu kertang dengan dosis $12 \mathrm{mg} / \mathrm{kg}$, yaitu dengan pertumbuhan bobot mutlak terbesar 3,85 g, diikuti oleh pemberian $\mathrm{r} E l \mathrm{GH}$ dengan dosis $6 \mathrm{mg} / \mathrm{kg}$, yaitu sebesar 3,29 g. Sedangkan pertumbuhan bobot mutlak terendah, yaitu sebesar 2,41 g terdapat pada perlakuan tanpa pemberian $\mathrm{r} E l \mathrm{GH}$, diikuti oleh pemberian $\mathrm{r} E l \mathrm{GH}$ pada dosis $18 \mathrm{mg} / \mathrm{kg}$ dan $24 \mathrm{mg} / \mathrm{kg}$, yaitu sebesar 2,60 g dan $2,50 \mathrm{~g}$.

Rasio konversi pakan terbaik (nilai rasio paling rendah), yaitu 1,10 diperoleh pada pemberian $\mathrm{r} E I \mathrm{GH}$ dengan dosis $12 \mathrm{mg} / \mathrm{kg}$, sedangkan rasio konversi pakan tertinggi yaitu, 1,40 terdapat pada perlakuan tanpa penambahan $\mathrm{r} E I \mathrm{GH}$.

Penurunan nilai konversi pakan pada ikan selais dapat disebabkan oleh pengaruh $\mathrm{r} E l \mathrm{GH}$ terhadap nafsu makan ikan. Penurunan nilai konversi pakan ikan juga pada perlakuan pemberian rElGH juga ditemukan pada ikan lele sangkuriang (Triwarsono et al., 2014) dimana nilai rasio konversi pakan mempunyai nilai terendah 0,457 . Hal ini dikarenakan nafsu makan yang bertambah setelah perendaman dengan rGH. Lebih lanjut Triwarsono et al. (2014) menyatakan bahwa hal ini sesuai dengan pendapat Matty (1985) bahwa 
rekombinan hormon pertum-buhan dapat meningkatkan nafsu makan, konversi pakan, sintesis protein, menurunkan ekskresi nitrogen, merangsang metabolisme dan oksidasi lemak, serta memacu sintesis dan pelepasan insulin.

Tingkat kelulushidupan ikan selais tertinggi $(100 \%)$ terdapat pada perlakuan kontrol dan penambahan $\mathrm{r} E I \mathrm{GH} 12 \mathrm{mg} / \mathrm{kg}$, sedangkan tingkat kelulushidupan ikan selais terendah terdapat pada pemberian rEIGH pada dosis $18 \mathrm{mg} / \mathrm{kg}$.

Kelulushidupan ikan selais selama masa pemeliharaan tidak jauh berbeda antar perlakuan. Kelulushidupan yang tinggi dan tidak berbeda nyata antar perlakuan dapat disebabkan oleh kualitas air media pemeliharaan ikan yang sesuai dengan kondisi dan padat tebar yang dibutuhkan oleh ikan untuk tumbuh optimal. Pemeliharaan ikan selais dilakukan secara intensif dimana kualitas air dikontrol agar tidak mempengaruhi pertumbuhan.

Tabel 2. Kualitas air media Pemeliharaan selama penelitian

\begin{tabular}{ccc}
\hline Parameter & $\begin{array}{c}\text { Awal } \\
\text { penelitian }\end{array}$ & $\begin{array}{c}\text { Akhir } \\
\text { penelitian }\end{array}$ \\
\hline $\mathrm{Suhu}\left({ }^{0} \mathrm{C}\right)$ & $27-31$ & $28-31$ \\
$\mathrm{pH}$ & $5-6$ & $5-6$ \\
$\mathrm{DO}(\mathrm{mg} / \mathrm{L})$ & $4,1-5,8$ & $4,7-6,4$ \\
$\mathrm{NH}_{3}(\mathrm{mg} / \mathrm{L})$ & $0,013-0,016$ & $0,013-0,073$ \\
\hline Dari & hasil & pengukuran
\end{tabular}

parameter-parameter kualitas air pada tiap perlakuan, tidak terlihat adanya perbedaan besar antar perlakuan. Kisaran nilai suhu selama penelitian yaitu $28^{0}-31^{0}$ CBoyd menyatakan kisaran suhu untuk organisme di daerah tropis adalah $25-32^{\circ} \mathrm{C}$ dan perbedaan suhu tidak lebih dari $10^{\circ} \mathrm{C}$.

Nilai $\mathrm{pH}$ air berkisar $5-7$. Nilai $\mathrm{pH}$ selama penelitian juga tidak mengalami perubahan signifikan dan ikan dapat beradaptasi dengan baik. Kisaran nilai $\mathrm{pH}$ selama penelitian ini sesuai dengan Syafriadiaman et al., (2005) yang menyatakan bahwa nilai $\mathrm{pH}$ yang baik untuk pemeliharaan ikan adalah berkisar antara 5 hingga 9 .

Kadar oksigen terlarut pada media pemeliharaan ikan selais selama penelitian yaitu berkisar 4,1-6,2 mg/L. Kisaran nilai ini masih dapat diterima oleh ikan menurut Boyd (1990) yang menyatakan bahwa konsentrasi oksigen bagi organisme di perairan adalah mendekati atau di atas 3 ppm.

Nilai amoniak selama masa pemeliharaan yaitu berkisar 0,013 $0,075 \mathrm{mg} / \mathrm{L}$. Kadar amoniak yang cenderung mengalami kenaikan pada akhir penelitian disebabkan karena terdapatnya feses ikan dan kotoran dari sisa pakan yang tidak dimakan oleh ikan. Namun kisaran nilai amoniak selama pemeliharaan ikan selais masih dapat ditolerir oleh ikan. Hal ini sesuai dengan Lesmana (2002) yang menyatakan kandungan amoniak di perairan tidak boleh lebih dari $1 \mathrm{ppm}$.

\section{Retensi protein dan lemak}

Retensi protein dan lemak ikan selais selama penelitian (Tabel 3).

Tabel 3. Nilai rata-rata $( \pm S E)$ retensi protein dan lemak ikan selais selama penelitian

\begin{tabular}{ccc}
\hline $\begin{array}{c}\text { Dosis } \\
\mathrm{r} E I \mathrm{GH}\end{array}$ & $\begin{array}{c}\text { Retensi protein } \\
(\%)\end{array}$ & $\begin{array}{c}\text { Retensi lemak } \\
(\%)\end{array}$ \\
\hline $0 \mathrm{mg} / \mathrm{kg}$ & $30.61 \pm 4.53$ & $39.33 \pm 2.51^{\mathrm{a}}$ \\
$6 \mathrm{mg} / \mathrm{kg}$ & $43.49 \pm 7.81$ & $97.60 \pm 10.47^{\mathrm{b}}$ \\
$\mathbf{1 2}$ & $\mathbf{4 6 . 7 3} \pm \mathbf{2 1 . 3 4}$ & $\mathbf{1 0 3 . 8 3} \pm \mathbf{2 1 . 4 3}$ \\
$\mathbf{~} \mathbf{6} / \mathbf{k g}$ & $32.38 \pm 6.84$ & $86.23 \pm 4.27^{\mathrm{b}}$ \\
18 & $32.36 \pm 17.67$ & $102.51 \pm 17.39^{\mathrm{b}}$ \\
$\mathrm{mg} / \mathrm{kg}$ & & \\
24 & & \\
$\mathrm{mg} / \mathrm{kg}$ & & \\
\hline
\end{tabular}

Pemberian rElGH pada dosis 12 $\mathrm{mg} / \mathrm{kg}$ telah memberikan hasil terbaik dalam meningkatkan pertumbuhan ikan. Pemberian rElGH pada dosis ini juga memberikan hasil terbaik terhadap retensi protein ikan selais. Tingginya nilai retensi protein ini menunjukkan kontribusi yang cukup besar dari protein dalam pakan terhadap pertumbuhan ikan selais. 
Pemberian $\mathrm{r} E l \mathrm{GH}$ pada ikan nila (Oreochromis niloticus) strain Sultana oleh Muhammad et al. (2014) selain dapat memperbaiki konversi pakan juga dapat meningkatkan retensi protein yang menunjukkan bahwa protein yang dimakan tidak banyak dirombak untuk energi dan terjadi biokonversi karbohidrat. Lebih lanjut Muhammad et al. (2014) juga mengutip pernyataan Perez-Sanchez (2000) yang menyatakan bahwa kemampuan retensi protein yang tinggi pada ikan yang diberi rGH menunjukkan bahwa hormon pertumbuhan mampu meningkatkan pemanfaatan nutrien non protein (karbohidrat) sebagai sumber energi (protein sparing effect).

Nilai retensi lemak tertinggi diperoleh pada pemberian $\mathrm{rElGH}$ pada dosis yang juga menghasilkan pertumbuhan terbaik yaitu $12 \mathrm{mg} / \mathrm{kg}$. Tingginya nilai retensi lemak pada ikan yang diberi rElGH juga ditemukan pada ikan sidat (Handoyo, 2012) dimana benih ikan sidat yang diberi perlakuan tumbuh lebih cepat dan memiliki ukuran yang lebih besar sehingga kandungan lemak di tubuhnya lebih tinggi dan secara langsung akan meningkatkan retensi lemak. Tingginya nilai retensi lemak pada ikan perlakuan rElGH menunjukkan tingginya proses lipogenesis yang terjadi dalam tubuh ikan.

\section{KESIMPULAN}

Pemberian hormon pertumbuhan rekombinan ikan kerapu kertang (rElGH) dosis $12 \mathrm{mg} / \mathrm{kg}$ pakan mampu mempercepat laju pertumbuhan ikan selais. Pertumbuhan terbaik ditandai dengan laju pertumbuhan harian sebesar $5,56 \%$, rasio konversi pakan sebesar 1.10 , retensi protein $46,73 \%$, dan retensi lemak sebesar $103.83 \%$.

\section{SARAN}

Disarankan penggunaan hormon pertumbuhan rekombinan kerapu kertang $(\mathrm{r} E l \mathrm{GH})$ dosis $12 \mathrm{mg} / \mathrm{kg}$ pakan dapat dilakukan guna mempercepat pertumbuhan ikan selais.

\section{DAFTAR ACUAN}

Abbas, B.F.I., 2013. Pertumbuhan Benih Ikan Betok (Anabas testudineus, Bloch) Yang Disuntik Hormon Pertumbuhan Rekombinan Ikan Kerapu Kertang Dengan Dosis Berbeda. Skripsi Fakultas Perikanan dan Ilmu Kelautan Institut Pertanian Bogor.

Alimuddin, I. Lesmana, A.O. Sudrajat, O. Carman, I. Faisal. 2010. Production and bioactivity potential of three recombinant growth hormones of farmed fish. Indonesian Aquaculture Journal. 5: 11-16.

Apriliana R., F. Basuki, R. Agung. 2017. Pengaruh Pemberian Recombinant Growth Hormone (rGH) Dengan Dosis Berbeda Pada Pakan Buatan Terhadap Pertumbuhan dan Kelulushidupan Benih Ikan Tawes (Puntius sp.). Jurnal Sains Akuakultur Tropis, 2 (1): 49-58

Desmelati, M. Ilza, Nuzirwan. Kajian Penerimaan Konsumer terhadap Ikan Asap Selais (Cryptoperus bicirchis) yang Dibuat Menggunakan Asap Cair. Jurnal Terubuk, 41 (1): 10-24

Handoyo, B. 2012. Respons Benih Ikan Sidat Terhadap Hormon Pertumbuhan Rekombinan Ikan Kerapu Kertang Melalui Perendaman dan Oral. [tesis]. 
Bogor (ID): Institut Pertanian Bogor.

Latar, D.I. 2010. Efektivitas Pemberian Hormon Pertumbuhan Rekombinan Melalui Pakan dengan Bahan Penyalut Berbeda dan Pelleting pada Ikan Nila. Tesis Sekolah Pascasarjana Institut Pertanian Bogor.

Muhammad, Alimuddin, Zairin M., Carman O. 2014. Respons Pertumbuhan dan Efisiensi Pakan Pada Ikan Nila Ukuran Berbeda Yang Diberi Pakan Mengandung Hormon Pertumbuhan Rekombinan. Jurnal Riset Akuakultur, 9 (3): 407-415

Prihardianto, R.W. 2014. Penentuan Dosis Perendaman Hormon Pertumbuhan Rekombinan Ikan Kerapu Kertang Pada Pascalarva Udang Galah. Skripsi Fakultas Perikanan dan Ilmu Kelautan Institut Pertanian Bogor.

Putra, I., N.A. Pamukas. 2011. Pemeliharaan Ikan Selais (Ompok sp.) Dengan Resirkulasi, Sistem Aquaponik. Jurnal Perikanan dan Kelautan, 16: $125-131$

Putra, R.M., Sukendi, Yurisman. 2011. Teknologi Domestikasi, Pembenihan dan Budidaya Ikan Selais (Ompok hypopthalmus) Dalam Rangka Meningkatkan Kesejahteraan Nelayan dan Petani Ikan Pinggiran Sungai Kampar, Riau. Laporan Penelitian Hibah Kompotetitif Penelitian Strategis Nasional Tahun II. Universitas Riau.

Rosyadi, A. 2015. Pertumbuhan dan kelangsungan hidup ikan selais Kryptopterus lais yang diberi hormon tiroksin. Jurnal Akuakultur Indonesia, 14 (1), $38-41$

Saputra, A. 2016. Pertumbuhan Udang Vaname Pada Tahap Pembenihan dan Pembesaran Pascarendam Hormon Pertumbuhan Rekombinan Ikan Kerapu Kertang. Tesis Sekolah Pascasarjana Institut Pertanian Bogor.

Sudrajat, A.O., M. Muttaqin, Alimuddin. 2013. Efektivitas hormon tiroksin dan hormon pertumbuhan rekombinan terhadap pertumbuhan larva ikan patin siam. Jurnal Akuakultur Indonesia, 12 (1): 31-39

Tang, U.M., H. Alawi. 2015. Pengaruh Penambahan Mineral Besi (Fe) Terhadap Pertumbuhan dan Tingkat Kematangan Gonad Ikan Selais (Ompok hypopthalmus). Laporan Hasil Penelitian Insentif Riset Sinas: Teknologi Proses Produksi Ikan Selais (Ompok hypopthalmus) Di Lahan Sub Optimal. Lembaga Penelitian dan Pengabdian Kepada Masyarakat Universitas Riau.

Tang, U.M., Z.A. Muchlizin, H. Syawal and H. Masjudi. 2017. Effect of water temperature on the physiological stress and growth performance of tapah (Wallago leeri) during domestication. Arch. Pol. Fish., 25:165-171

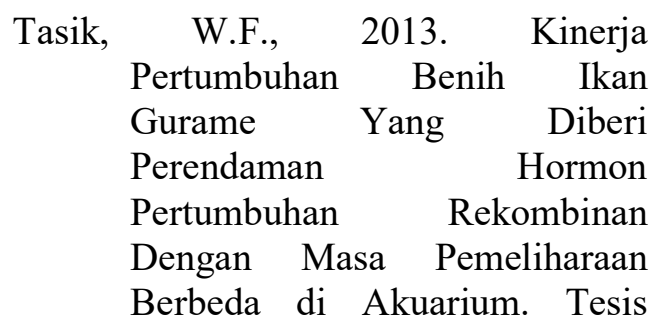


Sekolah Pascasarjana Institut Pertanian Bogor.

Triwinarso, W.H., F. Basuki, T. Yunarti. 2014. Pengaruh Pemberian Hormon Pertumbuhan Rekombinan (rGH) Melalui Metode Perendaman Dengan Lama Waktu yang Berbeda Terhadap Pertumbuhan dan Kelulushidupan Ikan Lele Varietas Sangkuriang. Journal of Aquaculture Management and Tecnology, 4: 265-272.

Wijaya, P.D.D., 2015. Pertumbuhan dan Reproduksi Induk Ikan Maanvis Disuntik Hormon Pertumbuhan Rekombinan Ikan Kerapu Kertang Dosis Berbeda. Skripsi Fakultas Perikanan dan Ilmu Kelautan Institut Pertanian Bogor.

\section{Email :}

maulina_sawitri@yahoo.com

usmanmt@yahoo.co.id

heni_ifoid@yahoo.com 